\title{
The level participation in efforts mount Kelud eruption disaster mitigation in East Java
}

\author{
Andri Estining Sejati ${ }^{1}$ *, Muhammad Hasan ${ }^{2}$, Desi Nurul Hidayati ${ }^{3}$ \\ ${ }^{1}$ Program Studi Pendidikan Geografi, Universitas Sembilanbelas November Kolaka. \\ Jalan Pramuka, Tahoa, Kolaka, Sulawesi Tenggara 93561, Indonesia \\ ${ }^{2}$ Balai Besar Pelatikan Kesehatan (BPPK) Makassar \\ Jalan Moha No. 59, Antang, Makassar, Sulawesi Selatan 90234, Indonesia \\ ${ }^{3}$ Program Studi Pendidikan Geografi, Universitas Negeri Surabaya \\ Jalan Rektorat Unesa, Lakarsantri, Surabaya, Jawa Timur 60213, Indonesia \\ andriest@usn.ac.id \\ * Corresponding Author
}

\section{ARTICLE INFO}

\section{Article History}

Received:

29 October 2019;

Revised:

31 October 2019

Accepted:

1 November 2019

\section{Keywords}

Eruption;

Disaster mitigation;

Level participation

\begin{abstract}
Indonesia location is between four plates, there are: Eurasian, IndoAustralian, Philiphines, dan Pasicic. Subduction between plates make Indonesia disturbed a natural incident such as mountain eruption. One of disturbed mountain eruption disaster area is District Ngancar, Kediri Regency. This case because Ngancar location near Kelud slope. People participation for efforts mitigations is very important for reduced natural incident impact. The aim this paper to discuss form and level people participation in District Ngancar for efforts Kelud mountain eruption disaster mitigation. This research is survey with sample 100 from 5.340 head family. The data collected with interview and documentation, then analized by quantitative description with scoring and percentage. The research result showing that people in disaster disturbed zone I, II, and III get participation score each the amount of $1.425,935$, and 1.133. The participation action, include: elucidation disaster, organizing disaster preparedness, preparing self, making early warning system, and saving property.
\end{abstract}

This is an open access article under the CC-BY-SA license.

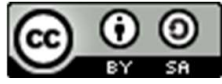


The level participationin efforts mount Kelud eruption ...

Andri Estining Sejati, Muhammad Hasan. Desi Nurul Hidayati

101

\section{INTRODUCTION}

Natural incident occur in Indonesia. That incident, such as: earthquakes, tsunamis, volcanic eruptions, landslides, droughts, and floods. Earthquakes, tsunamis, and volcanic eruptions are natural incident associated with tectonic activity. This is reasonable because Indonesia located between four tectonic plates, there are: Eurasian, Indo-Australian, Philippines, and Pacific. Plates push each other (converging) causes the tectonic and seismic activity. According to Wekke, Sabara, Samad, Yani, Umam, and Palu (2019) Indonesia's geology formed by three main world's plates, there are: Eurasia, India-Australia, and Pacific. Until now, humans have not been able to stop the emergence of hazards. Not only cause of its extraordinary strength, but also the time difficult to determine precisely. Natural incident is said to be a disaster when there are victim. Conditons in the human at Region can be predict the victim probability. According to Parwanto (2014) natural disaster is the seriously emergent condition with victims, survivors, and damaged areas. Natural disaster combine in biological, geographycal, hydrological, meteorological, and climatological classification. Humans have the ability to recognize and understand natural incident. The action is one of effort to reduce the level of damages or victim caused by a natural disaster, or often referred as part of disaster management. According to Kusumayudha, Lestari, and Paripurno (2018) the use of SMS gateway is expected able to increase public and government awareness in order to reduce risk and disaster victims. A variety of natural disaster hazards that comes without planned, Indonesian people living in disaster disturbed areas should prepare for a natural disaster to minimize the victims. One form of preparation is mitigation. According to Indonesia Law Number 24 of 2007, mitigation is a series of efforts to reduce disaster risk through physical development and awareness or increase to face disaster ability. According to Susanti and Khotimah (2017) mitigation effort before disaster can reduce impact or victim.

One of natural disasters always happened in Indonesia is volcanic eruption. Indonesia has 125 volcanoes and 83 are active until now. One of the active volcanoes in Indonesia is Mount Kelud. Kelud has the characteristics one eruption but strong. According to Atmojo, Rusilowati, Dwiningrum, and Skotnicka (2018) the character of eruption is important in disaster knowledge. Since 1900 until now Kelud erupted seven times, at: 1901, 1919, 1951, 1966, 1990, 2007, and 2014. Kelud did not follow the character in 2007 , because the eruption is effusive with lava dome mixed thick white smoke from the middle of the crater. According to Pilchin, Geoscience, and Company (2019) magma have characteristic to reach the survace, the slowly caused convecting sub-litosphere upper mantle. Kelud caused more than 15 thousand inhabitants, since the 15th century. Human lives victims more than 10 thousand in 1586. Almost every eruption of Mount Kelud set Disaster Disturbed Areas in Kediri, spread over four districts, there are: Ngancar, Puncu, Kepung, and Plosoklaten. That because the location close to the crater and in the flow lava direction (west to south). According to the Center of Volcanology and Geological Disaster Mitigation (PVMBG) Kelud in 1990, Ngancar District have total human victim 14 from 32 or 44\%, in 1966 eruption, there were 107 people die or 51\%. According to (Parwanto, 2014) in the 1966 kelud eruption victims are 1000 deaths.

The most vulnerable risk population of Kelud eruption in Kediri is Ngancar District by 3,656 populations. Distance Sugihwaras village, Ngancar District also closest to mount Kelud peak of 4.9 kilometers. Villages in Ngancar district also the largest entry in disturbed area as many as 6 from 14 villages that spread over four districts. The level of largest risk eruption of Mount Kelud (Area 3) all located in the Ngancar district, there is Sugihwaras and Sempu Village. Ngancar district people in addition to getting the blessing of fertile land, also had to be prepared for the eruption of Mount Kelud in order to reduce or eliminate losses. Ngancar District people preparedness can be public participation in the efforts related eruption mitigation. According to Shapira, Aharonson-Daniel, and Bar-Dayan (2018) preparadness is one of way to reduce the impact of disaster. Participation in this paper is all action, participation of the public on disaster preparedness eruption of Mount Kelud. Preparedness is for himself or organizations that participated in the community. The aim this paper to discuss form and level people participation in District Ngancar for efforts Kelud mountain eruption disaster mitigation. According to United Nations Secretariat for International Strategy for Disaster Reduction (2014) community participation is the disaster risk reduction function in around people. 


\section{METHOD}

This paper type of research is survey. The subject in this research is the people that in the disaster disturbed zone in the Ngancar District. The location in the Ngancar district, spread in the six village, there are: Sugihwaras, Sempu, Babadan, Ngancar, Margourip, and Manggis. The research was conducted in November 2012 and updated in February 2017. The population is 5,340 families. The sample calculation results with Slovin formula in Setiawan (2007) is 100. Then samples were taken by proportional random sampling technique of disaster disturbed area (III, II and I) respectively by 31,30 , and 39. The primary data are people participation in Ngancar District that in the disaster disturbed zone shape obtained by interviews with the questionnaire. Questionnaire is the instrument of this research with 17 question about 5 aspect participation. Five aspects are elucidation disaster, organizing disaster preparedness, preparing self, making early warning system, and saving property. Secondary data are common conditions such as: the number of population, area, map, victims of Mount Kelud eruption. Secondary data were obtained by documentation from institutions: the central statistics, the national disaster management agency (BNPB), district office, and photos. Data were analyzed by descriptive quantitative with scoring equipped percentage. The classification of participation count by interval class.

\section{RESULT AND DISCUSSION}

Result

Participation is all forms of people action in disaster response preparedness activities to the threat of Mount Kelud eruption. Engagement can be a mental and emotional involvement and also physical in use all the capabilities it has in all the activities carried out and supports the achievement of goals and responsibilities for all involved. People participation in the threat of Mount Kelud eruption consists of five indicators: 1.) Action in following outreach activities on disaster; 2.) Action in organizing community disaster response; 3.) Action in preparing for disaster response preparedness; 4.) Action in an early warning system; and 5.) Action in an attempt to save possessions. Firstly, action or something that is done when there are extension activities or disaster simulations. Acts committed that can be active or passive. Action parameters are: participation, attitude when extension, and participation (to prepare equipment and supplies) in extension activities or simulations. People participation in Ngancar District in extension activities and the greatest disaster simulation in the area III is $74.2 \%$, II $16.67 \%$, and $33.33 \%$ I. Attitudes conducted during counseling activities in area III have been better than area II and I. This because people in Area III think that counseling is important to face the impending eruption, considering the region closest to Mount Kelud. People participation in providing the basic needs of both throughout area no people become remain donator for extension activities. Residents only contribute helped needs/equipment, Area III $(51.62 \%)$, II (3.33\%), and I (28.2\%). Most of the population in area II never helped the extension activities because they think the region will not be affected by lava from Mount Kelud. Because of that, they feel no need to engage in providing extension activities equipment.

The second, action or activity in organizing communities disaster response facing the threat of eruption of Mount Kelud. Organizing disaster response in area III (45.16\%), II (26.67\%) and I (64.1\%) people follow the social organization. People in area are the most in the following community organizations because the more population and more accessible area of the vehicle. This causes the public easy to perform association or organization. The organization, there are: Youth, Women's, Community Leaders, Indigenous Organizations, Youth Masjid, Religious study groups, and also the Association of the elders. Elders some 30 people gathered once a year, when there will be Kelud larung sesaji event held once a year. Average routine follow associations or organizations in every area at monthly. Activities undertaken related to cope with disasters by creating a safe evacuation plan. Providing the necessary needs (food, clothing, medicines, and tents), for area II without medicine. Thirdly, any measures undertaken preparedness before a disaster occurs. Measurement of action, including: participation in following the development of Mount Kelud activity; The main ingredient earthquake-resistant houses volcanic and lava flows; action as it happens signs Kelud will erupt (such as volcanic earthquakes); and action taken if Mount Kelud 
erupted suddenly. Population in area III and I respectively of $56.61 \%$ and $53.85 \%$ always follow the development of Kelud and follow the instructions of the government, while in area II is $23.33 \%$. The all house in all area are made from wall with a foundation of stone. In the event of volcanic earthquakes are mostly just out of the house, specially in area III (41.94\%) out of the house and away from the tree to avoid falling debris of fallen trees. If Mount Kelud eruption there is $45.16 \%$ of people in area III would leave their homes if the lava flow has reached his home. According them if the lava flow has not reached their home means home is still safe and do not need to evacuate. But in area II and I respectively of $93.33 \%$ and $89.74 \%$ displaced to locations that have been set by the government, both the danger is imminent or not.

Fourthly is the creation of early warning system to detect Mount Kelud activity. Give warnings to prevent victim. Indicators action in establishing early warning systems, there are: forms, public participation in the making, and cared. Form of early warning systems in all area is a siren with an average of $76.75 \%$. Other shapes such as gong and microphone. Most people have never participated in making the early warning system. Treatment most if there is spare time, while for the area I and II 56\% don't know and never cared for the existing early warning system. Fifth, in addition to save self, the efforts action to save property such as: money, securities, and livestock. Most communities in the study area had livestock such as cattle. The government usually prepare a special refugee camps livestock. If at any time the eruption of Mount Kelud people in area III (67.74\%) and II $(83.33 \%)$ only save self, but at area I (30.77\%) save all assets owned. It shows that community participation in area I in terms of saving asset better than in area III and II. Based on the results of scoring five indicators, then for participation in community disaster preparedness Ngancar District can be seen in the following Table 1.

Table 1. Level of Public Participation Ngancar District

\begin{tabular}{cccc}
\hline Indicator & \multicolumn{3}{c}{ Area } \\
& III & II & I \\
\hline Action in following extension activities & 230 & 136 & 213 \\
Action in organizing disaster respone & 254 & 208 & 344 \\
Action in preparing/disaster respone & 345 & 326 & 448 \\
Action in establishing early warning system & 220 & 196 & 276 \\
Action in an attempt to save assets & 84 & 69 & 114 \\
Total Value & 1133 & 935 & 1425 \\
\hline
\end{tabular}

People participation in disaster response preparedness is low because minimum village socialization about disaster counseling. Besides that low people participation in the area II because the majority of people are in migrants, thus less concerned about the action or attitude on disaster response preparedness. The low participation in rescue possessions to make the score decreases. Most people $(>90 \%)$ in the three dangers area of letting livestock also other possessions and more concerned about safety self.

Discussion

Area III is the closest to the Mount Kelud which is just $5 \mathrm{~km}$ from Mount Kelud crater. Scores of people participation is 1133. Area III does not have the highest participation scores for saving property classified as very low. Most people prefer to think of the safety of lives than their possessions, including livestock. So when the eruption of Mount Kelud, the livestock they have to be left alone. According to Norfita and Krol (2014) people around Mouth Merapi prefer to not consider about the loss, but the eruption occurrences still give effects on their way of thinking, people realized that life was not only about prosperous. According to United Nations Secretariat for International Strategy for Disaster Reduction (2014) that Mexico, Kenya, and Bangladesh having the ministry that concern in the disaster in the part of livestock when accident occured. When viewed by age, people are mostly the elderly (61.29\%) aged over 40 years. Motivation is reduced because some old age creates lazy to pass through steep and rugged terrain so that they only focus on work. 
According to Pandey (2019) the community in the aims of reduce disaster motivate people to work together. Explanation of phenomena in quantitative data can be analyzed based on the result by percentage like Sukariasih, Purwana, Nursalam, Sahara, and Reskiawan (2019) research. Anccording to Benardi (2018) the young have high potention to participate and increase they knowledge about disaster.According to Sari (2019) the eldery age classification get the big percentage as victim in the Mount Merapi eruption, so can indicate that the eldery not have time and energy to participated in the disaster sosialization programe.

Majority people have experienced Kelud disaster much as two to three times. Based on these events they took the lessons of the disaster, so they do not think to participate in extension activities. Based on research data showing that time people stay is $41.94 \%$ between $41-58$ years. According to Sutrisno, Shih, Bin Hasim, Qin, Wicaksono, \& Syaifoel (2019) experiences with natural disaster have big efforts to encharge people cooperation in disaster management. According to United Nations Secretariat for International Strategy for Disaster Reduction (2014) in the Solomon Island, Samoa, Nepal, Fiji, Malaysia, British Virgin Islands, Germany, Srilanka, Australia, Turks and Caicos Islands, Mozambique, and Armenia mark the disaster experience in their mitigation. Based on the description above, which affect the low level of people participation on disaster response preparedness in area III are age, occupation and income, education, and terrain conditions. Conditions rugged terrain and steep will make people the difficulty in reaching the location of the extension, so that they would prefer to opt out of counseling or disaster response participation. Participation is a non-physical effort in minimizing the disaster. According to Setiawan, Kingma, and Westen (2014) mitigation measures can be divided into two main parts, namely the mitigation of structural/physical and non-structural/nonphysical. According to Susanti and Khotimah (2017) the level people participation in the efforts Mount Merapi Eruption disaster mitigation in zone 3 is medium, that mean people less active in the mitigation activity in structural or non structural.

Area II distance $10 \mathrm{~km}$ from Mount Kelud crater. People participation in disaster response preparedness score is 935. Indicators that make the low level of participation in area II than area III and I for longer stays shorter society. People in area II participation levels to follow the extension activities including low because can't socialize or understand the conditions around their homes because not long lived in the area so that the sense of belonging and attachment to the place is still lacking. According to Shapira, Aharonson-Daniel, and Bar-Dayan (2018) previous experience is one of the important poin in the count of disaster mitigation management system. People in KRB II, most have never experienced eruption disaster, because the time stay in the area is still less than 22 years. If people have to stay a minimum of 22 years ago it would have experienced Kelud eruption in 1990 and in previous years. This can be seen when the siren sounded in 2007, people didn't directly to save zone. According to Chantry and Norton (2019) practical experience can effect in the social in the way to disaster prevention. Based on monograph data Ngancar District in 2011, people in area II 913 from 1.575 households (58\%) are migran from another places. So for people who are not familiar with the area does not provide a large enough participation in all activities, especially in terms of outreach activities on Kelud disaster. Low participation because of low interaction and a sense of belonging to environment surrounding. According to Kusumayudha, Lestari, and Paripurno (2018), because the volcano not active for long time, people around Mounth Sinabung not prepared yet to facing the eruption. It is same as the migran who don't have experience. Area I is region or danger zone that is within $15 \mathrm{~km}$ from the summit of Mount Kelud. This area get the highest participation community score (1.425). Society has a level of experience of the disaster that was because of the high long stay mostly from birth. It makes people have high experienced about efforts Kelud disaster. Physical conditions in disaster disturbed zone I was more flat topography. People more easily to reach locations. According to Kusumayudha, Lestari, and Paripurno (2018) awakening of the volcano hypotetically can support people to know about the character of volcano. All area leaving the entire property and is more concerned with personal safety. Kelud has signs before eruption. Prior to the category of alert, the public should begin to evacuate animals and bring treasures. In 2014 after an explosive eruption a few military patrol keeping homes in the affected areas from looting. Possessions need to be saved for the purposes of post disaster or recovering from disaster. According to United Nations Secretariat for International Strategy for Disaster Reduction (2014) property in the various country had the way to protect it when disaster happend. 
Participation is important to mitigation. Eruption 1990 and previously was a lot. After 1990, in 2007 (effusive) and 2014 (explosive) there were no dead people victim in Ngancar District so did Kediri Regency. There are victim people deaths caused by the volcanic ash affected by respiratory problems, 2 people in Blitar Regency. According to Kusumayudha, Lestari, and Paripurno (2018) to reduce the risk, such a countermeasure should be developed especially that directly involving local people participation. According to Setiawan, Kingma, and Westen (2014) one of ways to reduce victim in the landslide disaster is participation of NGOs in disaster activities because helping the community when disaster strikes and enhancement of dissemination about landslide to the local community. According to Hariyono, Liliasari, Tjasyono, and Madlazim (2016) courses accordingly can help student to improve their participations to solve problems of volcanic eruption crisis in the society. Interview process in the people in Ngancar District is expeditious. The peole are welcome to this process. The interview data collection like the research (Retnawati, Djidu, Kartianom, Apino, $\&$ Anazifa, 2018) that primary data collect by interviews with questionnaire.

\section{CONCLUTION}

The research result showing that people in disaster disturbed area I, II, and III get participation score each the amount of 1.425, 935, and 1.133. The classification in all areas are low or the score get 2 from 4. Area III got the big two because the zone is closed with Kelud crater. Closed zone but no biggest score that because the location is steep with low accessibility, so they no always can acces elucidation place. Area II got the lowest score because majority people are immigrant. Although Area I the most far from Kelud crater, but almost all people born there. This can become them wary with story from their family who experienced the powerful eruption (example in 1990). Another reason the establish area I highest score is elucidation place easy to access by people. The low category in the area I because difficult acessibility to the counseling or socialization location, so the suggenstion is the area 1 need to build facilities and infrastructure to facilitate people present in the counseling or socialization location.

\section{REFERENCES}

Atmojo, S. E., Rusilowati, A., Dwiningrum, S. I. A., \& Skotnicka, M. (2018). The reconstruction of disaster knowledge through thematic learning of science, environment, technology, and society integrated with local wisdom. Jurnal Pendidikan IPA Indonesia, 7(2), 204-213. doi:https://doi.org/10.15294/jpii.v7i2.14273

Benardi, A. I. (2018). Pendidikan kesiapsiagaan bencana tanah longsor untuk siswa anak usia dini dengan metode dongeng berbasis media pop-up book di PAUD Dewi Sartika kecamatan Bergas. Jurnal Pendidikan Geografi, 23(2), 85-93. doi:https://doi.org/10.17977/um017v23i22018p085

Chantry, G., \& Norton, J. (2019). Social and economic inequality limits disaster prevention amongst the most vulnerable in Vietnam. Disaster Prevention and Management: An International Journal, 28(1), 50-59. doi:https://doi.org/10.1108/DPM-07-2018-0213

Hariyono, E., Liliasari, L., Tjasyono, B., \& Madlazim, M. (2016, February). Volcanic eruption crisis and the challenges of geoscience education in Indonesia. IP Conference Proceedings, Bandung, Indonesia. doi:https://doi.org/10.1063/1.4941190

Kusumayudha, S. B., Lestari, P., \& Paripurno, E. T. (2018). Eruption characteristic of the sleeping volcano, Sinabung, North Sumatera, Indonesia, and sms gateway for disaster early warning system. Indonesian Journal of Geography, 50(1), 70-77. doi:https://doi.org/10.22146/ijg.17574

Pandey, C. L. (2019). Making communities disaster resilient. Disaster Prevention and Management: An International Journal, 28(1), 106-118. doi:https://doi.org/10.1108/DPM-05-2018-0156 
106 - Harmoni Sosial: Jurnal Pendidikan IPS

Parwanto, N. B. (2014). Qualitative study on natural disaster risk management policy (Unpublished doctoral dissertation) National Graduate Institute for Policy Studies. doi:https://doi.org/10.1016/j.cell.2009.01.043

Pusat Vulkanologi dan Mitigasi Geologi Gunung Kelud. (2012). Data Korban Erupsi Gunung Kelud. Kediri: PVMBG Gunung Kelud.

Norfita, S., \& Krol, B. G. C. M. B. (2014). The livelihood analysis in merapi prone area after 2010 eruption. Indonesian Journal of Geography 46(2), 195-207. doi:https://doi.org/10.22146/ijg.5790

Pilchin, A., Geoscience, U., \& Company, E. C. (2019). Critical analysis of the plate tectonics model and causes of horizontal tectonic movements. New Concepts in Global Tectonics Journal, 4(2), 204-272.

Presiden Republik Indonesia. (2007). Undang-Undang Republik Indonesia Nomor 24 Tahun 2007 tentang Penanggulangan Bencana.

Retnawati, H., Djidu, H., Kartianom, Apino, E., \& Anazifa, R. D. (2018). Teachers' knowledge about higher-order thinking skills and its learning strategy. Problems of Education in the 21st Century, 76(2), 215-230. Retrieved from http://oaji.net/articles/2017/457-1524597598.pdf

Sari, M. M. (2019). Aplikasi peta Kawasan Rawan Bencana (KRB) dalam analisa sebaran korban erupsi ga. merapi 2010. Jurnal Spasial, 4(1), 10-20. doi:https://doi.org/10.22202/js.v4i1.1814

Setiawan, H., Kingma, N. C., \& Westen, C. J. Van. (2014). Analysis community's coping strategies and local risk governance framework in relation to landslide. Indonesian Journal of Geography, 46(2), 143-155. doi:https://doi.org/10.22146/ijg.5784

Setiawan, N. (2007, November). Penentuan ukuran sampel menggunakan rumus Slovin dan tabel Krejcie Morgan. Retrieved from http://pustaka.unpad.ac.id/wpcontent/uploads/2009/03/penentuan_ukuran_sampel_memakai_rumus_slovin.pdf

Shapira, S., Aharonson-Daniel, L., \& Bar-Dayan, Y. (2018). Anticipated behavioral response patterns to an earthquake: The role of personal and household characteristics, risk perception, previous experience and preparedness. International Journal of Disaster Risk Reduction, 31, 1-8. doi:https://doi.org/10.1016/J.IJDRR.2018.04.001

Sukariasih, L., Purwana, I. G., Nursalam, L. O., Sahara, L., \& Reskiawan, B. (2019). Improving the skill of hhysics science process through guide discovery method in students at senior high school. 227(Icamr 2018), 341-344. doi:https://doi.org/10.2991/icamr-18.2019.84

Susanti, E., \& Khotimah, N. (2017). Partisipasi masyarakat dalam mitigasi bencana di kawasan rawan bencana III gunung merapi desa Mranggen. Geomedia: Majalah Ilmiah Dan Informasi Kegeografian, 14(1). doi:https://doi.org/10.21831/gm.v14i1.13778

Sutrisno, D., Shih, P. T.-Y., Bin Hashim, M., Qin, R., Wicaksono, P., \& Syaifoel, R. (2019). Improving community capacity in rapid disaster mapping: An evaluation of summer school. Indonesian Journal of Geography, 51(2), 155-164. doi:https://doi.org/10.22146/ijg.40900

United Nations Secretariat for International Strategy for Disaster Reduction (UNISDR). (2014). Progress and challenges in disaster risk reduction: A contribution towards the development of policy indicators for the post-2015 framework on disaster risk reduction. The United Nations Office for Disaster Risk Reduction (UNISDR), 28-33.

Wekke, I. S., Sabara, Z., Samad, M. A., Yani, A., Umam, R., \& Palu, M. U. (2019, January). Earthquake, tsunami, and society cooperation: Early findings in Palu post of Indonesia disaster. International Conference on Challenges and Opportunities of Sustainable Environmental Development (ICCOSED), Universitas Prof. Dr. Moestopo (Beragama), Jakarta, Indonesia. 